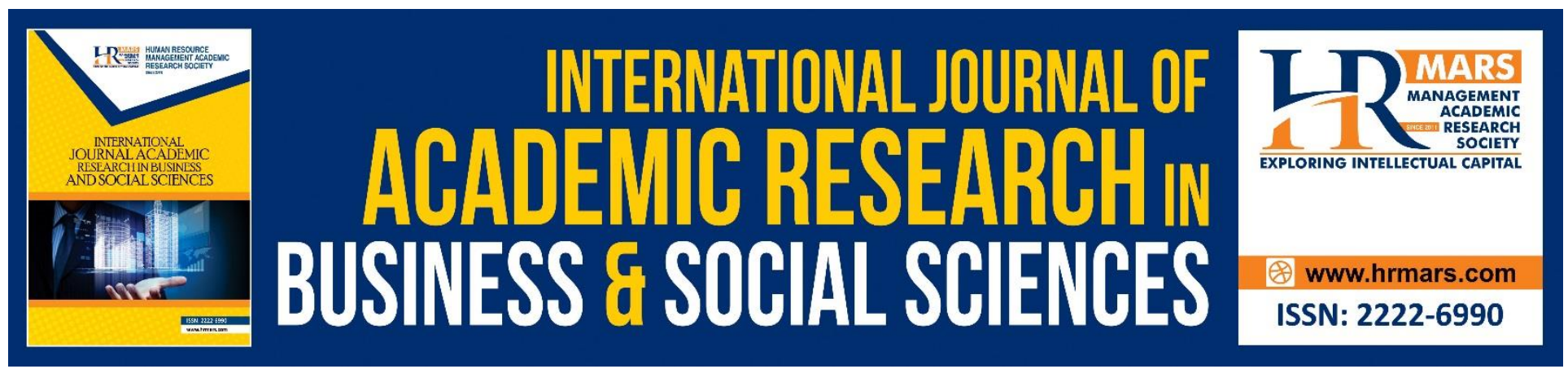

\title{
The History of Sisters in Islam
}

\section{Zuraidah Kamaruddin, Saidatolakma Yunus, Rahimah Embong, and Huda Afiqah Hashim}

To Link this Article: http://dx.doi.org/10.6007/IJARBSS/v8-i11/4929

DOI: $10.6007 /$ IJARBSS/v8-i11/4929

Received: 30 Oct 2018, Revised: 17 Nov 2018, Accepted: 03 Dec 2018

Published Online: 05 Dec 2018

In-Text Citation: (Kamaruddin, Yunus, Embong, \& Hashim, 2018)vv

To Cite this Article: Kamaruddin, Z., Yunus, S., Embong, R., \& Hashim, H. A. (2018). The History of Sisters in Islam. International Journal of Academic Research in Business and Social Sciences, 8(11), 551-558.

Copyright: (C) 2018 The Author(s)

Published by Human Resource Management Academic Research Society (www.hrmars.com)

This article is published under the Creative Commons Attribution (CC BY 4.0) license. Anyone may reproduce, distribute, translate and create derivative works of this article (for both commercial and non-commercial purposes), subject to full attribution to the original publication and authors. The full terms of this license may be seen

at: http://creativecommons.org/licences/by/4.0/legalcode

Vol. 8, No. 11, 2018, Pg. 551 - 558

http://hrmars.com/index.php/pages/detail/IJARBSS

JOURNAL HOMEPAGE

Full Terms \& Conditions of access and use can be found at http://hrmars.com/index.php/pages/detail/publication-ethics 


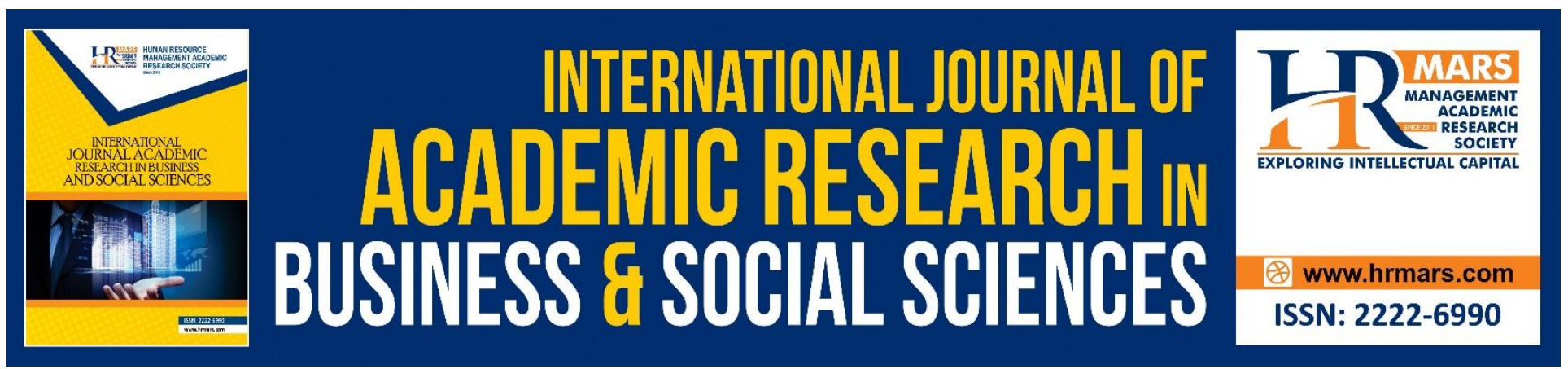

\title{
The History of Sisters in Islam
}

\author{
1'Zuraidah Kamaruddin, ${ }^{1}$ Saidatolakma Yunus, ${ }^{2}$ Rahimah Embong, \\ and ${ }^{3}$ Huda Afiqah Hashim \\ ${ }^{1}$ Kulliyyah of Islamic Revealed Knowledge and Human Sciences, \\ International Islamic University Malaysia \\ ${ }^{2}$ Faculty of General Studies \& Advanced Educations, Universiti Sultan Zainal Abidin, Malaysia \\ ${ }^{3}$ Persatuan Persaudaraan Muslimah, Malaysia (SALIMAH), Terengganu Chapter
}

\begin{abstract}
The emergence of Sisters in Islam (SIS) in Malaysia begins with their dissatisfaction of the implementation of certain new Islamic Family Law that had been legislated in 1984. In 1987, a group of women were not satisfied with certain law of the new Islamic Law when it was enforced in Shariah courts. They claimed that some existing laws which are implemented in the Shariah court in Malaysia are biased and discriminatory against Muslim women. The members of the group aim to reinterpret the texts of Islam because they believe that their proposed interpretations should be able to solve problems arising in society, especially those related to what they claim as gender inequality and human rights. Then, they proposed the method of a model of Qur'anic hermeneutics. This article found that the method of problem solving through a model of Qur'anic hermeneutics used by SIS does not fulfil the requirements of acceptable method for Qur'anic interpretation from an Islamic perspective.
\end{abstract}

Keywords: History, Sisters in Islam, A Model of Qur'anic Hermeneutics, Islamic Perspective

\section{Introduction}

In general, the word 'feminism' is associated with women who act, talk and write about women's issues and rights. They identify the existence of inequalities between the sexes in a community (Tandon, 2008). The word feminism itself first appeared in France in the 1880s, Great Britain in the 1890s, and then was used in the United States in 1910 (Tandon, 2008). Although issues that interest feminisms are varied, they strongly oppose social injustice in any community. They believe in the importance of analyzing and understanding gender differences by adding their own perspective in the goal to remove inequalities (Okin \& Mansbridge, 1994).

Research has recorded three "waves" of feminist movement. The first wave of feminism that occurred in the $19^{\text {th }}$ to early $20^{\text {th }}$ centuries dealt mainly with the Suffrage movement that emerged at the end of the $19^{\text {th }}$ century. They were concerned with women's right to vote. A second wave that took place from the 1960s up to the 1990s saw feminists fighting for legal equality as they believed 
that the civil law discriminated women. They wanted to ensure greater legal and basic human rights for women. The third wave of feminism arose in the 1990s where they continued their struggle on gender equality after the failure of the second wave movement (Tandon, 2008).

Feminism, which started as a movement for women's liberation is not of recent origin (I.Doi \& Bewley, 1989). According to the Oxford English Dictionary, the French dramatist Alexander Dumas was the first person who coined the term 'Feminism' in 1872. According to Neeru Tandon, "The term feminism is originated from the French. It is the combination word for woman, femme, and isme which referred to a social movement or political ideology."(Tandon, 2008). Barbara Berg gave the definition of feminism in her Introduction to The Remembered Gate: Origins of American Feminism as a "broad movement embracing numerous phases of women's emancipation". According to Berg, there are many kinds of freedom that women can achieve through the ideas of feminism such as the freedom to self-determination, freedom from prescribed sex roles, freedom from injustice regulations of society, freedom to show her whole ideas and freedom to practice their ideas. Feminism is the movement that struggle for women's freedom. They believe that women are discriminated because of their sex hence there is a need to free women from all types of injustice. A feminist is a woman who identifies herself as a feminist and the others also identify her as a feminist (Tandon, 2008). The word 'feminist' was also attributed to Charles Fourier, a French socialist, in the beginning of the 19th century (Tandon, 2008).

Feminism issues have not only become popular in the Western countries, its ideology is also spread to the Muslim world, where greater emphasis on gender issues is placed. They debated with the idea of women's freedom; they were convinced that women have limited freedom as compared to men. Feminists believe that the Muslim women should struggle to claim their rights (Muslikhati, 2004). However, some Egyptian, Turkish, Iranian, Syrian and Lebanese women and men were exposed to European feminist magazines even a decade earlier. In the general press, they discussed whether the feminism ideology can be applied to societies in the Middle-east or not (Muslikhati, 2004).

Most of Muslim feminist movements believe that it was not Islam that oppressed women rather it was the male-centered interpretations of the Islamic sources that discriminate the opposite sex. They claimed that this happened because of the influences of the cultural practices and values of a patriarchal society. They claimed that the realities of women have been largely silent in the interpretation of the Islamic sources. They also disputed over the male's interpretations of the Qur'an, whilst bringing with them an alternative interpretation from a woman's perspective (in relation to the Western version) (Frisk, 2009).

A feminist journal Zanan (Women) was founded in1992 is proof that there are voices from the Muslim feminists in Iran. This journal offers a new method of interpretations of Islam which they claimed will interpret the text fairly and without discrimination. It also called for equality between genders in terms of human rights. The goal of the journalist is to encourage women to be aware of their rights, proclaim it and then bring about a change to the society (Frisk, 2009).

Feminism does not only appear in the Middle-east countries, but was also spread to the other parts of the Muslim regions including the South-east Asia. Several South-east Asian Muslim women's groups play an active role in the current debates on the definition of the role of women's social, cultural, legal, and economy in their modern societies. They claimed that they seek to find the 
INTERNATIONAL JOURNAL OF ACADEMIC RESEARCH IN BUSINESS AND SOCIAL SCIENCES

Vol. 8, No. 11, Nov, 2018, E-ISSN: 2222-6990 @ 2018 HRMARS

teachings of the al-Qur'an to be applied to present-day context that are grounded on the idea of the universal equality of human beings in Islam. Groups of Muslim women led a re-examination of traditional Islamic sources for answers to these complex questions (Khanam 2002).

\section{Sisters in Islam (SIS)}

One of the South-east Asia countries includes Malaysia who has a prominent women's group struggling for equality between genders. This group is called the Sisters In Islam (SIS) who has been active in publishing writings and organizing seminars on this matter (Khanam 2002). The founding of SIS is traced to a certain law they were dissatisfied with when there was an implementation of new Islamic Family Laws that had been legislated in 1984. In 1987, a group of women were not satisfied with certain law of this new Islamic Law when it was enforced in Shariah courts. They claimed that some existing laws which are implemented in the Shariah court in Malaysia are biased and discriminatory against Muslim women. It seemed to them that Muslim women are oppressed by men or their husbands. They then suggested that some existing law in the Shariah court be reformed to ensure that the rights of Muslim women are protected under the law (Anwar \& Sidik, 2006).

There are eight women in this organization that make up the core of what was to become Sisters In Islam by 1989, and they are Amina Wadud, Askiah Adam, Norani Othman, Rashidah Abdullah, Rose Ismail, Salbiah Ahmad, Sharifah Zuriah Aljeffri, and Zainah Anwar (Anwar \& Sidik, 2006). In 1993, it was registered as a Non-Governmental Organisation (NGO) under the name of SIS Forum (Malaysia) Berhad (Osman, 2015). SIS's work expanded from focusing on a law reform to encompass larger issues of democracy, human rights and constitutionalism. Presently, the group claims that it holds weekly meetings to study the Qur'an and attempts to find the solution to the problems faced by Muslim women nowadays. They believe that some Family Laws that had been enforced at Shariah court in Malaysia discriminated against Muslim women and cannot solve the problems faced by them. Because of that, its area of study also included other sections of the Qur'anic text that the group believes had been used to justify domestic violence, polygamy, women's unquestioning obedience to men, the inferior position of women as witnesses, and gender inequality in general (Anwar \& Sidik, 2006).

SIS is currently doing research into the Qur'an, tafsir literature, Islamic law, and women's rights. They aimed at ensuring discussions on Islam and women's rights are covered through multiple perspectives and guided by the principles of justice and equality. The group then published two questions-and-answer booklets entitled: "Are Women \& Men Equal Before Allah?" and “Are Muslim Men Allowed to Beat Their Wives?” (Anwar \& Sidik, 2006).

SIS did not only deal with family issues, they began to expand their work on larger and global issues such as nation-building, governance, Islamisation, and the challenge of change and modernity. To achieve this mission, in 1992, SIS organized its first national conference on The Modern Nation State and Islam, revolving around issues of contemporary relevance to the Ummah (Anwar \& Sidik, 2006). In 1994, SIS submitted its memorandum to the Government on Domestic Violence Act. In this 
INTERNATIONAL JOURNAL OF ACADEMIC RESEARCH IN BUSINESS AND SOCIAL SCIENCES Vol. 8, No. 11, Nov, 2018, E-ISSN: 2222-6990 @ 2018 HRMARS

memorandum, they argued on religious and legal grounds of how Muslims should not be excluded from the jurisdiction of the proposed law (Anwar \& Sidik, 2006).

By the end of the 1990s, SIS expanded its tasks to include broader issues such as upholding democratic principles and the fundamental liberties guaranteed by the Federal Constitution. They also raised issues of human right principles, international treaties and conventions that were signed by the Malaysian government (Anwar \& Sidik, 2006). SIS claimed that its explicit aim is to reclaim a social justice agenda within Islam and to promote a more egalitarian interpretation of gender status and rights. SIS has published work on a number of topics concerning women's rights within Islam in general as well as on particular issues (Frisk, 2009).

This organization also looked into human rights and democratic movements in the country. By 1998, SIS finally established an office with permanent staff. Two founding members become codirectors and they are Zainah Anwar and Sharifah Zuriah Aljeffri (Anwar \& Sidik, 2006). To ensure their opinions and suggestion were made known to the public, SIS began to expand their discussion into public education. In the year 2000, they began work on a training module on women's rights in Islam (according to the understanding of SIS) and revived their original study sessions. In the beginning, these study sessions were open only to Muslim women, but soon they welcomed all men and women, including those of other faiths. SIS also began conducting two-day training programmes on women's rights in Islam that would explain about justice and equality according to what SIS understood (Anwar \& Sidik, 2006). Thereafter, SIS also began its service arm in 2003 by establishing a legal clinic offering legal counseling via email, fax, letters, telephone and face-to-face meetings (Anwar \& Sidik, 2006).

Today, SIS is a registered non-profit company, has organized supporters and volunteers into the Friends of SIS (FOSIS) and includes male associate members. They now operate from a larger office in Petaling Jaya and have several full-time staff, part-time staff and project staff which involve academics from local universities in its research projects (Anwar \& Sidik, 2006). SIS also regularly consults members and associate members in its work on diverse issues. Several Kuala Lumpur-based members are active in writing letters to newspapers, magazines, etc. In its aim to create and expand public space to debate on women's rights and Islam, SIS also networks with other women's groups and NGOs working on human rights issues (Misra \& Chandiramani, 2005). SIS has extensively worked with other NGOs, both local and transnational, and is frequently featured in the local media (Peletz, 2009).

Aihwa Ong writes about SIS who claims that they encouraged women to become aware about equality rights between sexes from an Islamic perspective based on an Islamic framework through interpretations given by women instead of men. Some Muslim feminists in Malaysia argue that women should be well educated not only in religious matters but also in secular knowledge. Some of them believe that ijtihād should be applied by using independent reasoning to interpret the Islamic sources for themselves instead of relying only on male interpretations. According to them, this is an opportunity for women to be involved in public debates over religious matters that affect them and 
their community's future. They believe that the emphasis on careful reading of the Qur'an and other key Islamic writings allow for a new interpretation to explain religious matters according to the correct meaning without discriminating the women (Willford \& George, 2005).

SIS believes that Islam does not discriminate against women, but some interpretations of the Qur'an that had been done by man should be reviewed and corrected again. This means that SIS wants women to be given the opportunity to get involved in the interpretation of the Qur'an so that the perspective of women will be considered too. The member of this organization who entrusted to lead the task of interpretation is Amina Wadud (Anwar \& Sidik, 2006). In 1992, Amina Wadud-Muhsin began her reinterpretations of the Qur'an (Frisk, 2009).

This group claimed that Amina Wadud and a group of professional women are returning to the text of the Qur'an to understand how the Qur'an defines gender. They searched for tools that were available from within the Islamic tradition for the realization of equality between sexes. Hence, SIS developed various methods to highlight gender injustice and began to develop upon hermeneutical recovery projects. The projects aimed at reexamining the male interpretation monopolies on religious knowledge and gender constructions. This reform of religious knowledge then would be brought to the society through conferences, workshops, legal clinics, and etc. It also offers discussions of religious beliefs and practices. Apart from that, it also has publications ranging from press releases to letters to newspaper editors, legal memoranda, working papers and books. These publications aimed to achieve their target which was the national level. In addition, SIS has not only developed it at the national level, they wanted to reach the international level (Kirk-Duggan et al, 2010).

However, the question here is: Do the Sisters In Islam follow the steps and methods deduced by our great Muslim scholars to ensure that they make the correct interpretation (tafsir) of the Qur'an? If we look in to the method of a model of Qur'anic hermeneutics as suggested by the group, we will find that this method does not fulfil the proper method as determined by Muslim scholars of this field. If the group wishes to reinterpret the Qur'an, they have to follow the steps and method as determined by the great Muslim scholars. They have to begin their interpretation (tafsir) of each verse in the Qur'an by the Qur'an first, then interpretation (tafsir) of the Qur'an by the Sunnah, interpretation (tafsīr) of the Qur'an by șahābah, interpretation (tafsīr) of the Qur'an by tābi'ūn, and then interpretation (tafsir) of the Qur'an by opinion.

Hence, the only acceptable interpretation (tafsir) is that which adheres to the proper method as deduced by our great Muslim scholars. Besides that, the group also has to make sure that any member of its group who wants to interpret or reinterpret the Qur'an should fulfil the qualifications of a mufassir. Only a Muslim who meets the conditions as a mufassir is allowed to interpret the Qur'an. Within the aspect of who is qualified to interpret the Qur'an and Sunnah, whether man or woman, the group should acknowledge that there are no Muslim scholars who have claimed that women are prohibited from interpreting the Qur'an. Both men and women are allowed to engage 
INTERNATIONAL JOURNAL OF ACADEMIC RESEARCH IN BUSINESS AND SOCIAL SCIENCES

Vol. 8, No. 11, Nov, 2018, E-ISSN: 2222-6990 C 2018 HRMARS

themselves in the interpretation of the Qur'an as long as they are able to fulfil the qualifications as mufassir and follow the outlined methods.

Thus, if the woman member of the group wishes to interpret the Qur'an, this is not prohibited, but the woman who wishes to interpret it should be qualified in doing so. It is not a matter of whether a man or a woman is interpreting the text, rather it is the concern of whether they meet the qualifications or not.

Besides that, SIS also have to understand the meaning of justice as has been defined in the Qur'an and Sunnah, and not only just solely based on their mind. It is because the misunderstanding of the word "justice" will lead to the inappropriate solution.

The study found that the method of a model of Qur'anic hermeneutics as suggested by SIS will open a wider field of interpretation without limitation. This method will also allow others to interpret the Qur'an incorrectly. Our great Muslim scholars have already determined the methods and conditions for those who wish to interpret the Qur'an. These methods and conditions have been debated and agreed upon to avoid discrepant interpretations. The method of a model of Qur'anic hermeneutics as suggested by this group is based merely on relative interpretation, suspicion, doubt and life experience.

Then, another question arises; do Muslims require the method of a model of Qur'anic hermeneutics to help them understand the actual meaning of the Qur'an? The answer is of course no, because the method of interpretation of the Qur'an implemented by our mufassir is clear and includes every knowledge to help the mufassir understand the text of the Qur'an.

\section{Conclusion}

The study found that the group's formation started in 1987 as a part of the Association of the Women Lawyers (AWL) when several women lawyers and their friends gathered to concentrate on problems relating to the implementation of certain new Islamic Family Laws that were enforced in that year. Then, it led to the formation of the core of what was to become Sisters In Islam (SIS) in 1989, and in 1993, they were registered as a Non-Governmental Organisation (NGO) under the name of SIS Forum (Malaysia) Berhad.

The members of the group aim to reinterpret the texts of Islam because they believe that their proposed interpretations should be able to solve problems arising in society, especially those related to what they claim as gender inequality and human rights. In other words, they want to offer an alternative problem solving for society. One of the methods of problem solving that is claimed to be used by SIS in solving problems is through a model of Qur'anic hermeneutics.

Even though the method of a model of Qur'anic hermeneutics mentions a few principles that are acceptable and necessary in the work of interpretation, they are insufficient in obtaining the actual meaning of the interpretation of the text. There are many other principles and guidelines that must be followed and fulfilled by the group in order to obtain the true meaning of the verses. In 
addition to this, there are also principles of SIS's interpretation method that are too general and can lead to free interpretation without limitation. Moreover, some of SIS's principles of interpretation contradict with the general principles of Qur'anic interpretation as determined by Muslim scholars of this field. Thus, the method of problem solving through a model of Qur'anic hermeneutics used by SIS does not fulfil the requirements of acceptable method for Qur'anic interpretation from an Islamic perspective.

\section{Corresponding Author}

Asst. Prof. Dr. Zuraidah Kamaruddin, Department of Fids, Kulliyyah of Islamic Revealed Knowledge and Human Sciences, International Islamic University Malaysia.

Email: zurashukri@iium.edu.my

\section{References}

Anwar, Z. \& Mohd Sidik, S.S. (n.d.), Sisters in Islam, Empowering Voices for Change, Annual Review 2006, ed. Rose Ismail.

Frisk, S. (2009), Submitting to God: Women and Islam in Urban Malaysia, Denmark: Nordic Institute of Asean Studies (NIAS Press).

I. Doi, A.R. \& Bewley, A. (1989), Woman in Shari'ah (Islamic Law), Ta-Ha.

Khanam, R. (2002), Muslim Feminism and Feminist movement: South-East Asia, Delhi: Global Vision Publishing House.

Kirk-Duggan, C.A., Kassam, Z., \& Ashcraft-Eason, L.(2010), Women and Islam, ABC-CLIO.

Misra, G. \& Chandiramani, R. (2005), Sexuality, Gender and Rights: Exploring Theory and Practice in South and Southeast Asia, SAGE.

Okin, S.M. \& Mansbridge, J. (1994), Feminism, England: Edward Elgar Publishing.

Peletz, M.G. (2009), "Islam and the Cultural Politics of Legitimacy: Malaysia in the Aftermath of September 11," in Remaking Muslim Politics: Pluralism, Contestation, Democratization, Robert W. H. New Jersey: Princeton University Press.

Siti Muslikhati (2004), Feminism dan Pemberdayaan Perempuan dalam Timbangan Islam, Indonesia: Gema Insani.

Tandon, N.(2008), Feminism: a Paradigm Shift, New Delhi: Atlantic Publishers and Distributors (P) LTD.

Willford, A.C. \& George, K.M. (2005), Spirited Politics: Religion and Public Life in Contemporary Southeast Asia, SEAP Publications.

Interview:

Osman, R. (Executive Director, SIS Forum (Malaysia) Berhad, Petaling Jaya), in an interview with one of the writers, January 28, 2015. 